\title{
Alzheimer's disease in one monozygotic twin
}

\author{
RICHARD HUNTER, A. D. DAYAN, AND JOHN WILSON \\ From the Friern Hospital, London; Department of Neuropathology, National Hospital, Queen Square, \\ London; M.R.C. Clinical Genetics Research Unit, Institute of Neurology, London
}

SUMMARY A woman of 64 died after an illness lasting 15 years and characterized by a progressive amnesic syndrome followed by global dementia. The brain showed changes typical of Alzheimer's disease. Her monozygotic twin sister was clinically not affected and died two years later of carcinoma. This is the second report of monozygotic twin sisters apparently discordant for presenile dementia of Alzheimer type.

The literature on the genetics of Alzheimer's disease has recently been reviewed by Pratt $(1967,1970)$. Cases appear to fall into two groups according to whether or not there is a positive family history. In the minority a condition with pathological features resembling those of the disease has been transmitted as a dominant trait. About 12 families of this kind have been reported. Their close intrafamilial resemblance and regular Mendelian ratios suggest that they differ aetiologically from the common run of sporadic cases seen in clinical practice. These form the great majority and in them familial incidence is exceptional and a genetic factor uncertain.

It is possible that unrelated conditions which are pathologically similar have been confused with the clinicopathological entity eponymously called Alzheimer's disease (Dayan, 1971). An example is the family recorded as suffering from presenile dementia of Alzheimer type by McMenemey, Worster-Drought, Flind, and Williams in 1939, in which the histopathology was recently revaluated as familial cerebrovascular amyloidosis with superimposed Binswanger's disease (McMenemey, 1970).

Nevertheless, because there is doubt about a genetic component in true Alzheimer's disease, it is important to add to the scanty evidence from twin studies. So far only one monozygotic pair has been reported (Davidson and Robertson, 1955) but without laboratory evidence for uniovularity. Histologically proven Alzheimer's disease was present in one only. Here we report a second pair of monozygotic twins apparently discordant for the disease.

\section{CASE HISTORY: AFFECTED TWIN}

M.K., a spinster, born July 1902, was admitted to hospital in October 1965 aged 63 because of profound dementia. The illness started about 1952 with personality change and paranoid development, followed by a progressive amnesic syndrome leading to global dementia and finally total social incapacity.

FAMILY HISTORY M.K. and her twin sister, E.T., were adopted in infancy. Little was known of their parents but they were not related. A sister was born paralysed and died young.

PREVIOUS ILLNESSES. She had a mastoidectomy in 1935 and multiple injuries with concussion sustained in an air raid in 1941.

ON EXAMINATION. The patient was an elderly, illkempt, thin woman. General examination negative apart from seborrhoeic dermatitis (? atypical psoriasis) of scalp and flexures, and mildly elevated blood pressure of $150 / 90 \mathrm{~mm} \mathrm{Hg}$. She had a severe amnesic defect with global intellectual impairment and personality deterioration. Neurological examination showed intact cranial nerves, no sensory change, generalized increase in muscle tone most marked at proximal joints, and a tendency to adopt and maintain bizarre postures. Deep reflexes were brisk and equal, abdominals absent, plantar responses flexor.

INVESTIGATIONS Urine, routine haematological tests, blood sugar, urea, alkaline phosphatase, thyroid function tests, and cerebrospinal fluid were all 
within normal limits. WR and Kahn were negative. An EEG showed severe generalized abnormalities with background activity consisting mainly of theta and delta rhythms without focal or lateralizing features. Lumbar pneumoencephalography revealed prominent central and cortical atrophy.

PSYCHOMETRY. This confirmed the severe amnesic syndrome in a setting of advanced intellectual impairment but with preservation of some expressive verbal facility and a tendency to confabulate.

PROGRESS. There was some initial improvement in her physical condition accompanied by weight gain but her mental state steadily deteriorated. She died totally demented, speechless, wasted, and bed-ridden in March 1967 aged 64 years.

NECROPSY. Death was due to confluent bronchopneumonia. The brain was generally atrophic with wasting most marked over the frontal and occipital poles. The remaining findings were not abnormal, in particular the cerebral blood vessels and coronary and other major arteries were free from atheroma.

Histological examination of the brain showed large numbers of argyrophilic plaques in the cortex and a generalized loss of neurones. Many cortical neurones contained neurofibrillary tangles. These changes were most prominent in the cornu Ammonis where granulovacuolar degeneration was also seen in the cytoplasm of the pyramidal neurones.

\section{CASE HISTORY: UNAFFECTED TWIN}

E.T., twin sister of M.K., was examined in October 1966 at the age of 64 years. She did not think that she and M.K. were identical but acknowledged that their looks and build had been alike in childhood. Indeed, at the time of examination their appearance contrasted markedly. E.T. dyed her hair, wore make-up, and made a generally smart and lively impression. In contrast, M.K. looked vacant, was grey-haired and edentulous. Nevertheless, their height, build, eye colour, and iris composition were very similar.

E.T. was the more active and sociable of the two. She had married while M.K. had not. Her medical history was unremarkable: as a child she had broken a leg, and aged 50 had an inguinal herniorrhaphy. For some years she had noticed a swelling in her neck. She smoked and drank freely. The twins had lived apart in different towns in England for some 30 years. Neither had been abroad. They joined up again in their late 50s because of M.K.'s growing incapacity.

on EXAmination. She was a good witness and intellectual and memory functions were well preserved. General and neurological exmination were negative except for the presence of a thyroid nodule.

ELECTROCEPHALOGRAPH This showed a low voltage record with scanty 11-12 Hz alpha rhythm which was responsive to visual attention. Background 0 activity contained some random theta components of similar amplitude. On overbreathing the formation of the alpha rhythm improved. Photic reponses were symmetrical.

PSYCHOMETRY On the Wechsler Adult Intelligence Scale her verbal IQ was 101, performance IQ 91 . Verbal test scores were consistent within the average range and performance scores were consistent within the low average range. There were no discrepancies $a$

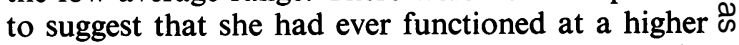
level. Learning and memory functions tested on the $\vec{O}$ Babcock sentence, recall of short story, and knowledge of current events were slightly impaired in $\bar{\omega}$ excess of what would be expected for her age.

PROGRESS She was seen again 18 months later in April 1968. No formal examination was made. No o change could be discerned in her general appearanc $₫$ manner or mental state and this was confirmed bo her son. In the autumn she began to complain of 0 malaise and respiratory distress on exertion. Tes for thyrotoxicosis were negative. In January 1969 a 0 carcinoma of the bronchus was discovered and squamous carcinoma cells were found in her sputure. By then operation was not considered justifiable ant she was treated with deep $x$-ray. She died of malis $\overrightarrow{0}$ nant cachexia in May 1969 aged 66 years. Permission $N$ for necropsy was not obtained.

\section{GENETIC STUDIES}

FINGER PRINTS Both sisters had loop patterns on all digits. The ridge counts were:

\begin{tabular}{|c|c|c|c|c|c|c|c|}
\hline & & I & II & III & IV & $\mathbf{V}$ & Total \\
\hline \multirow[t]{3}{*}{ M.K. } & $\mathbf{R}$ & 13 & 5 & 3 & 12 & 9 & 42 \\
\hline & $\mathbf{L}$ & 14 & 6 & 7 & 14 & 11 & 52 \\
\hline & & & & & & & 94 \\
\hline \multirow[t]{3}{*}{ E.T. } & $\mathbf{R}$ & 12 & 8 & 13 & 13 & 13 & 59 \\
\hline & $\mathbf{L}$ & 9 & 5 & 6 & 12 & 13 & 45 \\
\hline & & & & & & & 104 \\
\hline
\end{tabular}

Since $26.92 \%$ of monozygotic twins and only $\gg$ $6.93 \%$ of dizygotic twins show a difference of only․ㅡ․ 8-12 ridges, the relative probability of M.K. and N E.T. being dizygotic was almost $0 \cdot 25$. 
BLOOD GROUPS Results of blood group phenotype analysis were:

\begin{tabular}{|c|c|c|c|c|c|c|c|c|c|c|c|c|c|}
\hline & ABO & MNS & $\mathrm{P}_{1} \mathrm{Rh}$ & $\mathrm{Lu}^{\mathrm{a}}$ & K & $\mathrm{Le}^{\mathrm{a}}$ & $\mathrm{Le}^{\mathrm{b}}$ & $\mathrm{Fy}^{\mathrm{a}}$ & $\mathrm{Fy}^{\mathrm{b}}$ & $\mathrm{Xg}^{\mathrm{a}}$ & $\mathrm{Jk}^{\mathrm{a}}$ & $\mathrm{Jk}^{\mathrm{b}}$ & $\mathrm{Do}^{\mathrm{a}}$ \\
\hline & A & MNS & $+\mathrm{R}_{1} \mathrm{r}$ & - & & - & + & - & + & - & + & - & - \\
\hline & A & MNSs & $+\mathrm{R}$ & - & - & - & + & - & + & - & $\dot{T}$ & - & \\
\hline
\end{tabular}

From Smith and Penrose's (1955) tables, it was calculated that the chance of M.K. and E.T. being dizygotic was $0 \cdot 02$.

BIOCHEMICAL MARKERS The following data from studies of serum and red-cell isoenzymes (Giblett, 1969) were obtained:

\begin{tabular}{|c|c|c|}
\hline Serum enzymes & M.K. & E.T. \\
\hline Haptoglobin & $2-1$ & $2-1$ \\
\hline Transferrin & $\mathrm{C}$ & $\mathrm{C}$ \\
\hline $\begin{array}{r}\text { Serum cholinesterase } \mathrm{C}_{5}+\text { or }- \\
\mathrm{U}, \mathrm{I}, \text { or } \mathrm{A}\end{array}$ & $\overline{\mathrm{U}}$ & $\overline{\mathrm{U}}$ \\
\hline Red-cell enzymes & & \\
\hline Acid phosphatase & BA & BA \\
\hline Glucose-6-phosphate dehydrogenase & $\mathrm{A}$ & A \\
\hline Phosphoglucomutase & 1 & 1 \\
\hline Adenyl kinase & 1 & 1 \\
\hline
\end{tabular}

CUmulative analysis Combining the data from fingerprint, blood group, and biochemical analysis, the probability that the twins were dizygotic is less than 1 in 10,000 .

\section{DISCUSSION}

There is no doubt that M.K. suffered from Alzheimer's presenile dementia. Age at onset, evolution of symptoms, and duration all pointed to the diagnosis which was proved by histopathological findings. That she and her twin sister E.T. were monozygotic was confirmed by data from finger prints, blood group analysis, and biochemical markers. The evidence that E.T. was not affected remains presumptive. Ultimate proof from negative neuropathological examination was lacking, as it was in the unaffected sister of Davidson and Robertson's (1955) twins, because her brain was not available for study. However, absence of clinical manifestations is generally taken to imply absence of disease. The converse argument that similarity of clinical picture implies like pathology is invoked in family studies of Alzheimer's disease and Alzheimer-like conditions, for instance in those of Sjögren, Sjögren, and Lindgren (1952) in the majority of whose cases only the brain of one affected member was examined.
When E.T. was first seen she appeared clinically normal. This impression was confirmed by psychometry, which however revealed some impairment of recent memory in the test situation. Unexpectedly, her EEG also showed a minor abnormality. It was not known at the time that she was accustomed to taking alcohol in quantity, a habit which may have begun to take permanent effect. There was no progression during the remaining $2 \frac{1}{2}$ years of her life. When seen 18 months later, her behaviour and mental state were as before. No tests were made, but there was no evidence of the memory disturbance, spatial disorientation, or lack of spontaneity which characterize the early years of Alzheimer's disease (Sourander and Sjögren, 1970). No defects of this kind were observed when she was in hospital a few months before she died and was specifically examined for focal cerebral symptoms and signs. By then 17 years had passed since the disease became manifest in her twin, and E.T. was $66 \frac{1}{2}$ years old. After the age of 65 years it becomes increasingly difficult to distinguish Alzheimer's disease from Alzheimerlike changes of the senium. The clinical picture of the disease may in fact be caused by subtler pathological differences such as impoverishment of neuronal connections due to degeneration of dendrites or actual loss of nerve cells, rather than plaques and tangles which also accompany normal and pathological ageing due to other causes (Dayan, 1971). The possibility remains that there are late forms of Alzheimer's disease showing clinical deviations from the classical form whose histological appearance cannot always be distinguished from the changes of senescence. For this reason the name 'démence sénile alzheimerisée' (Arab, 1954) has been suggested as a compromise.

Alzheimer's disease has been known since the original account was published in 1907. It was given wide publicity by Kraepelin (1910) and it is not uncommon (Tariska, 1970). Yet not a single pair of twins of whom both were affected has been reported, whereas this is the second pair apparently discordant for the disease. It suggests 
that in the search for causes attention to exogenous rather than inborn factors may prove more fruitful. No significance can at present be attached to both pairs being women, nor that the duller twin was affected both in Davidson and Robertson's (1955) case and in ours. If the evidence for discordance is accepted, it would also strengthen the view that the much smaller group of familial Alzheimer-like cases should be regarded as a separate entity.

We thank Dr. D. A. Pocock, H.M.'s Coroner's pathologist in North London, for the necropsy report on M.K. and for making the brain available for study; Dr. R. R. Race and Dr. Ruth Sanger for the blood group analyses; Professor Harry Harris and Dr. Bette Robson for determining the biochemical markers; Dr. Michael Huntley for the finger print studies; and the Registrar General and the Registrar of the Inner London Executive Council for help in tracing the after-history of E.T.

\section{REFERENCES}

Alzheimer, A. (1907). Über eine eigenartige Erkrankung der Hirnrinde. Allgemeine Zeitschrift für Psychiatrie, 64, 146148.

Arab, A. (1954). Plaques séniles et artériosclérose cérébrale. Revue Neurologique, 91, 22-36.

Davidson, E. A., and Robertson, E. E. (1955). Alzheimer's disease with acne rosacea in one of identical twins. Journal of Neurology, Neurosurgery, and Psychiatry, 18, 72-77.
Dayan, A. D. (1971). Presenile dementia: some pathological problems and possibilities. Proceedings of the Roval Society of Medicine, 64, 829-831.

Giblett, E. R. (1969). Genetic Markers in Human Blood. Blackwell: Oxford.

Kraepelin, E. (1910). Psychiatrie. 8te Aufl. Bd. 2, p. 624. Barth: Leipzig.

McMenemey, W. H. (1970). In Alzheimer's Disease and of Related Conditions. A Ciba Foundation Symposium, pp. 132-133. Edited by G. E. W. Wolstenholme and M. O'Connor. Churchill: London.

McMenemey, W. H., Worster-Drought, C., Flind, J., and Williams, H. G. (1939). Familial presenile dementia. $\overrightarrow{\vec{F}}$ Journal of Neurology and Psychiatry, 2, 293-302.

Pratt, R. T. C. (1967). The Genetics of Neurological Disorders, pp. 74-76. Oxford University Press: London.

Pratt, R. T. C. (1970). The genetics of Alzheimer's disease. In Alzheimer's Disease and Related Conditions, pp. 137- $\overparen{\nabla}$ 143. A Ciba Foundation Symposium. Edited by G. E. W. @ Wolstenholme and M. O'Connor. Churchill: London.

Sjögren, T., Sjögren, H., and Lindgren, Å. G. H. (1952). Morbus Alzheimer and Morbus Pick. Acta Psychiatrica et. Neurologica Scandinavica, Suppl. 82.

Smith, S. M., and Penrose, L. S. (1955). Monozygotic and dizygotic twin diagnosis. Annals of Human Genetics, 19, 273-289.

Sourander, P., and Sjögren, H. (1970). The concept of Alzheimer's disease and its clinical implications. In or Alzheimer's Disease and Related Conditions, pp. 11-36. A ir Ciba Foundation Symposium. Edited by G. E. W. Wolstenholme and M. O'Connor. Churchill: London. $\stackrel{+}{\mathbb{D}}$

Tariska, I. (1970). Circumscribed cerebral atrophy 영 Alzheimer's disease: a pathological study. In Alzheimes Disease and Related Conditions, pp. 51-69. A Ciba Fou dation Symposium. Edited by G. E. W. Wolstenholme art M. O'Connor. Churchill: London. 